\author{
A.A. Sumbembayev ${ }^{1,2} *$, A.N. Danilova ${ }^{2}$ \\ ${ }^{\text {I} A l-F a r a b i ~ K a z a k h ~ N a t i o n a l ~ U n i v e r s i t y, ~ A l m a t y, ~ K a z a k h s t a n ; ~}$ \\ ${ }^{2}$ Natural flora Laboratory, Altai Botanical Garden, Ridder, Kazakhstan \\ *Corresponding author: aydars@list.ru
}

\title{
State of the relict species Abies sibirica Ledeb. in the natural monument «Sinegorskaya fir grove» (Koktau mountains)
}

\begin{abstract}
The article presents the results of studies of Siberian fir (Abies sibirica Ledeb.) in the natural monument «Sinegorskaya fir grove». In order to study the current state and development of the relict population field expeditions were conducted. By route-reconnaissance method the main occupied areas of the population on Mountain Medvedka were observed: the eastern, northern and western slopes, as well as two peaks. The studied population is represented by all age groups. There are 3 main types of $A$. sibirica Ledeb. phytocenoses: birch-fir (Betula pendula Roth, A. sibirica Ledeb.), fir (A. sibirica Ledeb.) and fir-aspen (Populus tremula L., A. sibirica Ledeb.). Parameters such as the height of mature trees, annual growth, length of young needles and the amount of young undergrowth have been determined. It has been established that the regeneration of the species directly depends on the type of phytocenosis. Based on the results of observations of the state, renewal and dispersal of Siberian fir only birch-fir communities are characterized by optimal conditions. In communities with aspen the species is severely oppressed. Diseases and pests were found in clean plantations. The limiting factors for the species are xerophytization of the habitat and the lack of sufficient soil layer. As additional protection measures to increase regeneration artificial re-sowing of seeds and planting of fir seedlings were suggested. Constant monitoring of the state of the population was proposed.
\end{abstract}

Keywords: Abies sibirica Ledeb., Kalba ridge, Sinegorskaya fir grove, relict species, cenopopulation.

\section{Introduction}

Among the most widespread conifers in the Republic of Kazakhstan, the most interesting is the vulnerable relict species Abies sibirica Ledeb. Growing area is the East Kazakhstan region, in the mountain forests of Altai, Tarbagatai and Dzhungarskiy Alatau [1-2]. A. sibirica is one of the main forest-forming species of the dark coniferous taiga, but it is rarely able to form pure stands [3]. Individuals of Siberian fir should go through latent, virginal and reproductive periods in their ontogeny [4]. However, the stages of development change significantly due to anthropogenic load and climate change.

There is unique natural monument, the Sinegorskaya fir grove (Koktau mountains) on the Kalba highlands. The area of about 50 hectares on Mountain Medvedka is occupied only by fir population [5] (Fig. 1).

The relief of the Kalba ridge is distinguished by its complexity and diversity. The large geomorphological units determine the features of the relief. They differ both in orographic appearance and in the history of origin, development and geological structure [6-8]. There is a mixture of the flora of the steppe and mountain zones due to the intermediate location of the Kalba ridge at the junction of the Altai mountain system and the Kazakh hillock. Geographical location of the ridge determines the richness of its territory with unique natural objects [5]. There is nemoral relict complex on the slopes of Mountain Medvedka. It consists from the species Polystichum braunii (Spenn.) Fée, Dryopteris filix-mas (L.) Schott, Athyrium filix-femina (L.) Roth, Festuca altissima All., F. gigantea (L.) Vill., Daphne altaica Pall., Iris ludwigii Maxim., I. glaucescens Bunge, Spiraea trilobata L., Thalictrum foetidum L., T. isopyroides C.A. Mey., Agropyron tarbagataicum N. Plotn., Allium nutans L., Tulipa heteropetala Ledeb., Hedysarum songoricum Bong., Melica transsilvanica Schur, Brachypodium pinnatum (L.) Beauv., Betula rezniczenkoana (Litv.) Schischk., Allium hymenorhizum Ledeb., A. altaicum Pall. 


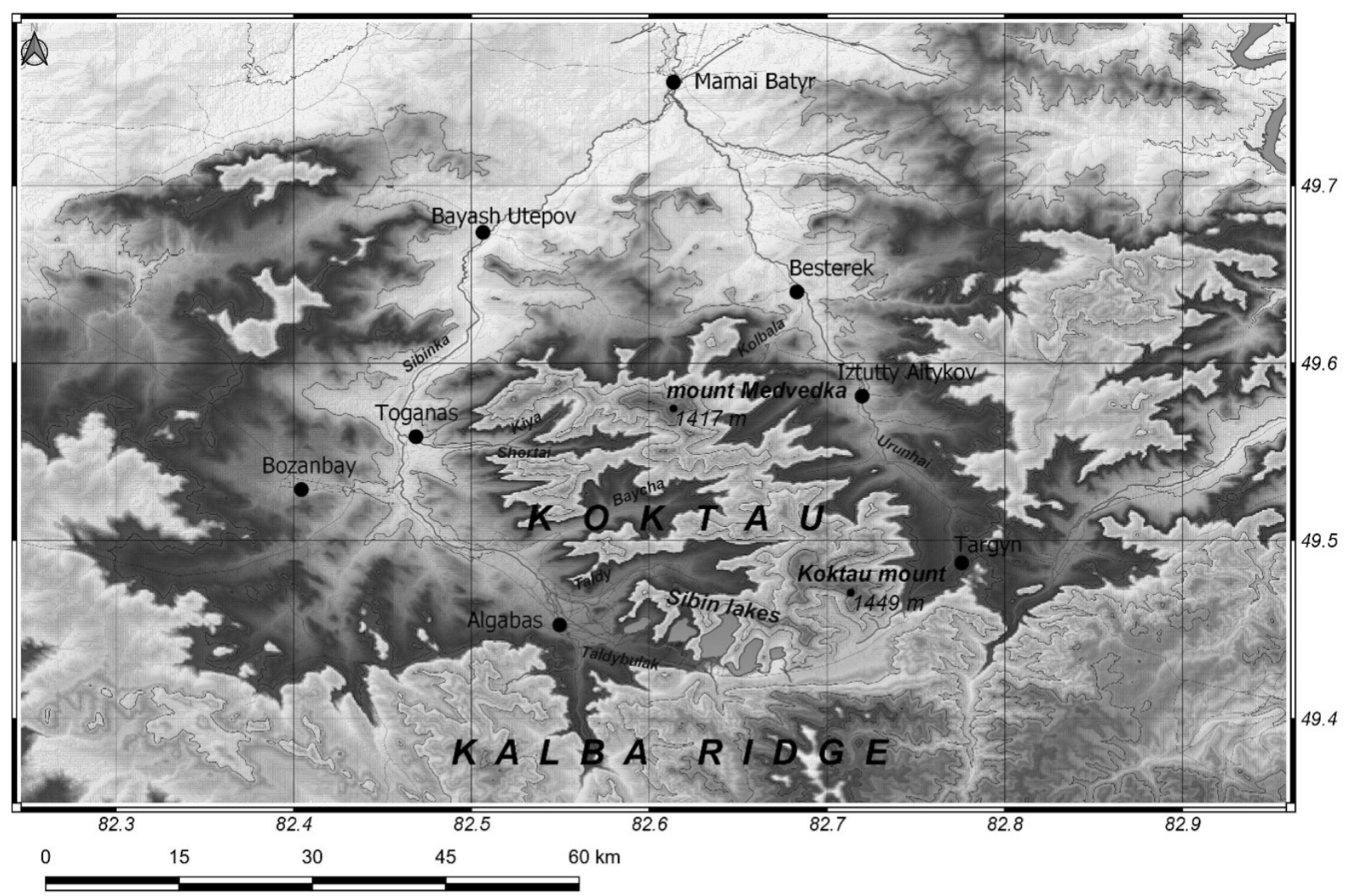

Figure 1. Location of the studied population on the Kalba ridge

There are few data on the biological characteristics of fir [9-12], especially regarding the state and development of Kazakhstan ecocenotypes, it requires additional research.

The purpose of this study is defining the state of vitality and development of the Siberian fir population in the Sinegorskaya fir grove.

\section{Materials and methods}

Field expeditions were carried out in 2018-2019 years. The study of the state of A. sibirica cenopopulations was carried out on the territory of the Sinegorskaya fir grove on Mountain Medvedka, in the Koktau mountains.

The study of the current state of $A$. sibirica cenopopulations in natural habitats was carried out by the route-reconnaissance method [13] using the classical methods of V.N. Golubev, E.F. Molchanov [14], L.V. Denisova, S.V. Nikitina, L.B. Zaugolnova [15]. To compile the ecological and phytocenotic characteristics of cenopopulations and to study the morphology of plants the generally accepted geobotanical methods were used $[16,17]$. The abundance of species is given according to G. Drude's scale. Latin names are verified according to the Plant List [18].

\section{Results and its discussion}

As a result of field research, it was established that Siberian fir occupies most of the Mountain Medvedka: the eastern, northern and western slopes, as well as two peaks (Fig. 2). 


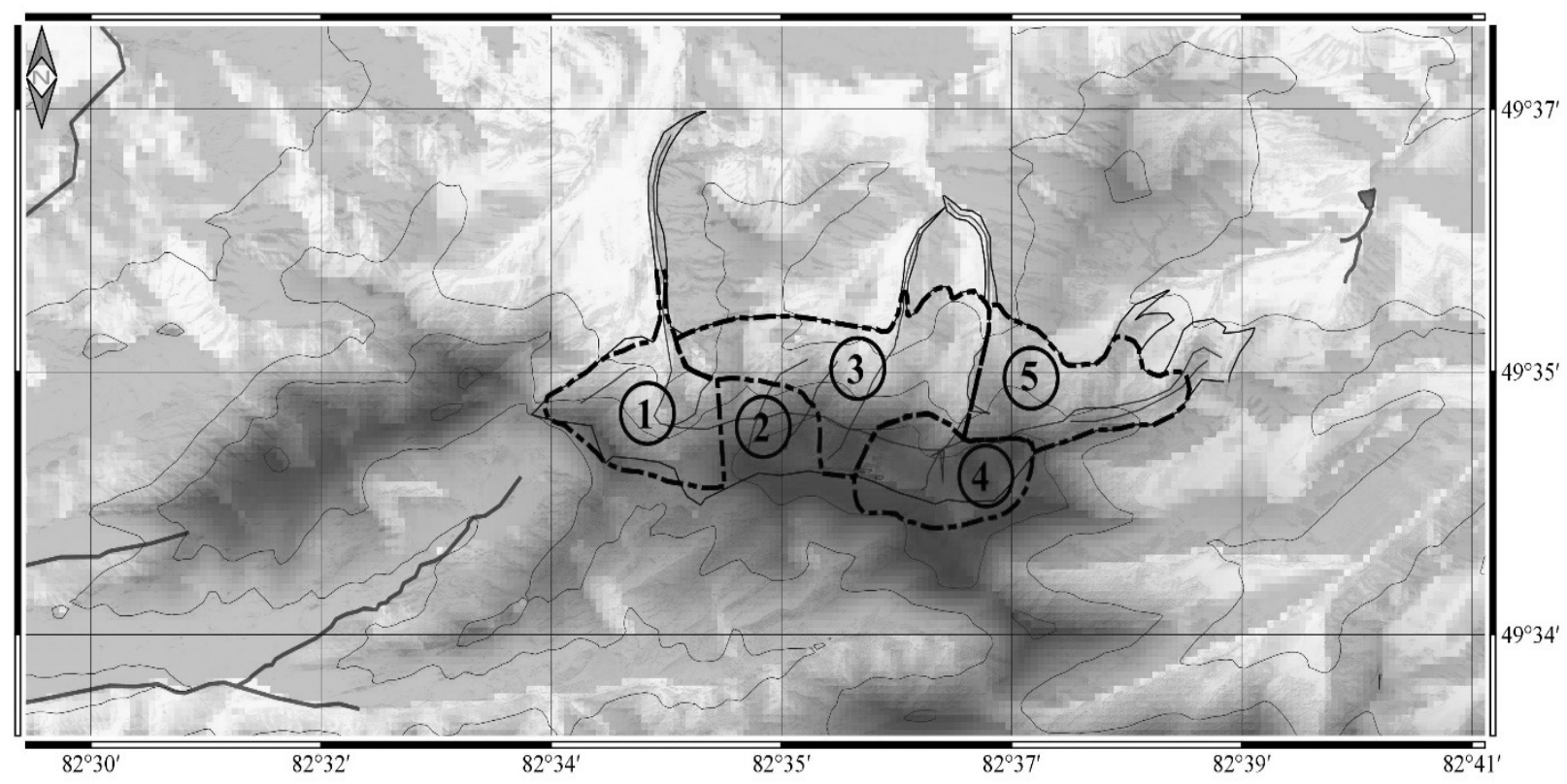

Figure 2. The slopes of Mountain Medvedka, occupied by fir:

1) western slope; 2) northwestern peak; 3) northern slopes; 4) southeastern peak; 5) eastern slope

The eastern slope is rather gentle, extensive, with large ledges and depressions. Location coordinates: $49^{\circ} 34^{\prime} 45^{\prime \prime} \mathrm{N}, 82^{\circ} 37^{\prime} 15^{\prime \prime} \mathrm{E}, 1314 \mathrm{~m}$ above sea level. The slope varies from 20 to $30-35^{\circ}$, in some places up to $40^{\circ}$. The relief is complex with numerous rock outcrops. It is composed of a large number of mattress granitoids of various sizes. The soil substrate is mountain chernozem (in places forest chernozem), abundantly humus. The soil horizon is impressive, reaching $60 \mathrm{~cm}$ in depressions. The soil accumulates only in crevices and depressions. Plant litter is $90-100 \mathrm{~g} / \mathrm{m}^{2}$. The plant litter is poorly expressed, in places it is completely absent. The water balance of the territory is limited, represented only by rare precipitation.

The main type of vegetation on the eastern slope is fir (A. sibirica Ledeb.) phytocenosis.

The dominants are $A$. sibirica - $\operatorname{cop}_{3}, B$. pendula - sol. Under the canopy of the tree layer prevailing species are Populus tremula L. — sp, Rosa pimpinellifolia — sol, Spirea media Franz Schidt — sp, Lonicera tatarica L. - sp, Sorbus sibirica Hedl. - sol. Most shrubs are concentrated in depressions where humus and water accumulate. There are weakened shrubs with curved crowns, with unsatisfactory development.

The grass stand is sparse, almost not formed, represented by separate lawns from Agrostis gigantea Roth - $\mathrm{cop}_{2}$, Carex macroura Meinsh. - $\mathrm{cop}_{2}$ и Galium boreale L. - sol, less often with such species as: Artemisia commutata Bess., Lupinaster pentaphyllus Moench, Galium verum L., Galatella punctata (Waldst. \& Kit.) Nees, Sonchus arvensis L., Dracocephalum ruyschiana L., Gypsophilla altissima L., Rubus idaeus L., Galium boreale L., Thalictrum flavum L., Athyrium filix-femina (L.) Roth, Woodsia ilvensis (L.) R. Br., Adenophora lilifolia (L.) A. DC., Lathyrus vernus (L.) Bernh., Woodsia alpina (Bolt.) S.F. Gray, Pleurospermum uralense Hoffm., Festuca altissima All., Veronica longifolia L., Rubus saxatilis L., Veronica pinnata L., Poa transbaicalica Roshev., Berberis sibirica Pall., Dianthus superbus L., Crepis sibirica L.

Forb and forb-shrub communities (Rosa pimpinellifolia L., Caragana arborescens Lam., Rosa acicularis Lindl., Cotoneaster melanocarpus Fisch. ex Blytt) with rare single inclusions of Siberian fir prevail at the foot of the slope.

The ecological conditions for the growth of the species are extreme. There are lack of soil depth and the presence of rock outcrops. The state of A. sibirica is suppressed. A considerable absence of undergrowth is noticed. Mature forms are sick, weakened, affected by rust. The tops are dry, which is associated with pollution of the soil and air with toxic substances, primarily sulfur dioxide.

Windbreak and windfall trees are common. The crowns of mature trees are curved, asymmetrical, young individuals are one-sided. Skirt crowns are rare or not pronounced. The annual growth rate is $2-6 \mathrm{~cm}$ $(3.55 \pm 1, \mathrm{Cv}=37 \%, \mathrm{Cv}$ is hereinafter the coefficient of variation of the trait).The length of young needles varies within $1.2-1.5 \mathrm{~cm}(1.4 \pm 0.27, \mathrm{Cv}=22 \%)$. The height of mature trees ranges from 7 to $18 \mathrm{~m}(14.88 \pm$ $4.01, \mathrm{Cv}=33 \%)$.

Fir plants are located unevenly in small groups, sometimes in stripes. 
The number of young undergrowth is up to 2-4 (1.4) self-sown plants per $100 \mathrm{~m}^{2}$. Renewal is almost non-existent. There is a reaction to altitude change. The higher the place of growth on the slope, the more coniferous rust is presented. Frost cracks are quite rare and insignificant. The main limiting factors for the species are the ecological conditions of habitation and the lack of a sufficient soil layer. The relief is not suitable for the normal development of the species.

The southeastern peak of Mountain Medvedka is diverse in relief forms. In some places, there is an abundant outcrop of rocks. The soil layer is poorly formed, concentrated between rock crevices and in depressions. In some areas, the soil horizon is quite well developed, up to $50-60 \mathrm{~cm}$ deep. The litter is abundant, well overheated, up to $120-140 \mathrm{~g} / \mathrm{m}^{2}$. The water balance is at the optimal level due to good spring snow retention.

The stand is represented by fir-birch phytocenosis type (Betula pendula Roth, A. sibirica L.). Location coordinates: $49^{\circ} 34^{\prime} 35^{\prime \prime}$, 82 $37^{\prime} 04^{\prime \prime}, 1373 \mathrm{~m}$ above sea level.

The arboreal layer is of the same type, represented exclusively by two species: $B$. pendula - $\operatorname{cop}_{1}, A$. sibirica - cop $_{1}$. The shrub layer is well developed under the canopy, which consists of Salix viminalis L. sol, Caragana arborescens Lam. — sol, Spirea media Franz Schmidt — sol, Juniperus sibirica Burgsd. sp, Sorbus sibirica Hedl. - sol, Cotoneaster melanocarpus Fisch. ex Blytt — sol, Populus tremula L. — sp. The herbaceous layer is poor in terms of species. The layering of the herbage is not expressed due to the low dispersal density of herbaceous species. Common species for herbage are Humulus lupulus L. — sp, Phleum phleoides (L.) Karst. — sol, Polygola comosa Schkuhr — sol, Artemisia sieversiana Willd. — sol, Sedum hybridum L. - sp, Bistorta major S.F. Gray — sol, Dianthus superbus L. — sp, Agrostis gigantea Roth sp, Vicia cracca L. - sol, Atragena sibirica L. — sol, Lilium martagon L. - sp, Thalictrum flavum L. sol, Trollius altaicus C.A. Mey — sol, Veratrum lobelianum Bernh. — sol, Cirsium incanum (S.G. Gmel.) - sol.

The condition of the individuals is good. The height of mature trees is $15-20 \mathrm{~m}$. The crowns are symmetrical, regular in shape, often with skirt bases. Rare slabs strongly deform tree trunks. The annual growth is within $2-3(2.35 \pm 0.28, \mathrm{Cv}=17 \%) \mathrm{cm}$. The length of young needles is $1.5-2(1.88 \pm 0.14, \mathrm{Cv}=11 \%)$ $\mathrm{cm}$.

The undergrowth of $A$. sibirica is rare or almost absent. The number of young undergrowth ranges from 2 to $6(3.14 \pm 1.26)$ per $100 \mathrm{~m}^{2}$. The species renewal is weak. Senile individuals predominate in the age spectrum. Phytocenosis with a clear right-sided spectrum. Fruiting is weak. The state of the species directly depends on the depth of the soil cover and the absence of granitoid plates on the earth's surface. Dwarf forms are not rare. Needle rust is low. No pests were found Frost cracks are rare and insignificant.

The northwestern peak of Mountain Medvedka is represented by fir-aspen type of phytocenoses

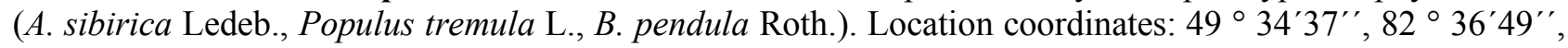
$1296 \mathrm{~m}$. The relief is not homogeneous, rather complex; often there is an outcrop of rocks. The slope is quite well moistened due to abundant snow retention.

The dominant species are A. sibirica Ledeb. - $\operatorname{cop}_{2}$, P. tremula L. - $\operatorname{cop}_{2}$. B. pendula Roth - sol is rare. Shrub layer is 1-1.5 m height and consists of Caragana arborescens Lam. - cop ${ }_{1}$, Sorbus sibirica Hedl. — sol, Spirea media Franz Schmidt — sol, Rosa pimpinellifolia L. - sol. Herbaceous layer characterized by lowdensity and cover, species - poor. Rare individuals represent it: Aconitum leucostomum Worosch — sol, Vicia pisiformis L. - sol, Thalictrum flavum L. — sp, Sausurea latifoliaLedeb. — sp, Poa nemoralis L. - sol, Bupleurum longifolium L. subsp. aureum (Fisch ex Hoffm.) Soo - sol, Atragene sibirica L. - sol, Galium verum L. — sol, Heracleum sibiricum L. — sol, Trollius altaicus C.A. Mey. sol, Fragaria vesca L. - sol.

A. sibirica Ledeb. well developed, well formed. Mature senile individuals predominate, $15-22 \mathrm{~m}$ in height. Young individuals are usually up to $1 \mathrm{~m}$ in height, abundant: 2-7 per $100 \mathrm{~m}^{2}$. There are individuals of all age categories.

Rust on the needles is not observed. Drying of the tops of the trees is almost absent. Windfall and windbreak trees are extremely rare. The tree crowns of $A$. sibirica are regular, symmetrical. Frost cracks are not marked. In this community, the competition between woody plants did not reach visible rivalry, and A. sibirica is not clearly oppressed by $P$. tremula. The annual growth varies from 2.2 to 3 (2.67 \pm 0.5 ; $\mathrm{Cv}=25 \%) \mathrm{cm}$. The length of young needles is $1-2.5(1.85 \pm 0.39 ; \mathrm{Cv}=28 \%) \mathrm{cm}$.

This community is a typical mountain-forest formation for this slope. Due to the high level of overgrowth bedrock, granitoid slabs have almost no effect on the development of tree species. 
The western slope of the mountain. There are two types of represented phytocenoses.

Aspen-fir ( $P$. tremula L., A. sibirica Ledeb.) phytocenosis. Location coordinates: $49^{\circ} 35^{\prime} 01^{\prime \prime} \mathrm{N}$, $82^{\circ} 36^{\prime} 34^{\prime \prime} \mathrm{E}, 1111 \mathrm{~m}$ above sea level. The density of individuals of the species is 01-02. Density of crowns is 01. Rare shrubs and young trees are represented under the canopy: Sorbus sibirica Hedl. - sol, Ribes rubrum L. - sol, B. pendula Roth - sol. The slope is quite steep. Steepness up to 50-55\% in some places, often with outcropping of rocks (granite slabs). The soils are mountain chernozems, the layer is thin, up to 40 $\mathrm{cm}$, in depressions up to $50 \mathrm{~cm}$, abundantly saturated with overheated humus. The herbaceous layer, with a fairly high density and coverage, is represented by turf grasses and sedges. Thalictrum isopyroides C.A. Mey. - sol-sp, Veratrum nigrum L. - sol, Bupleurum multinerve DC. - sol, Hierochloe odorata (L.) Beauv. - sol, Galium verum L. - sol, Galium boreale L. — sol, Humulus lupulus L. — sol, Spirea media Franz Schmidt — sp, in some places there are island lawns from Sedum hybridum L. — sp, Spirea trilobata L. - sol with the inclusion of Lilium martagon L. - sol, Sedum hybridum L. prevails on the rock outcrops.

A. sibirica Ledeb. at senile phase of growth is rather tall. It often curved at the base. The height of the trees reaches $15-17 \mathrm{~m}$. Undergrowth is found only on the edges, where aspen root suckers are not developed. Young undergrowth is usually $2-3$ vegetative individuals, rarely almost none. Aspen can presumably replace fir. Individuals with a skirted crown extensively cover the base of the trunks near the ground with creeping branches.

The crown is symmetrical, fairly aligned, sometimes one-sided (naked from the south-west). Mass diseases and pests were not found. No dry top was found. The annual growth varies from 2 to $2.8(2.4 \pm 0.3 ; \mathrm{Cv}$ $=17 \%) \mathrm{cm}$. The length of young needles is $1-1.8(1.3 \pm 0.2 ; \mathrm{Cv}=21 \%) \mathrm{cm}$.

Birch-fir communities (B. pendula Roth, A. sibirica Ledeb.). Location coordinates $49^{\circ} 34^{\prime} 56^{\prime \prime} \mathrm{N}$, $82^{\circ} 36^{\prime} 19^{\prime \prime} \mathrm{E}, 1235 \mathrm{~m}$ above sea level.

There are rather well developed communities, richer in species. The tree layer is of the same type, with a density of $07-08$, consists of only 2 species: B. pendula Roth - $\operatorname{cop}_{2}$, A. sibirica Ledeb - $\operatorname{cop}_{2}$.

The relief of the slope is rather difficult. The underbrush is abundantly presented by Sorbus sibirica

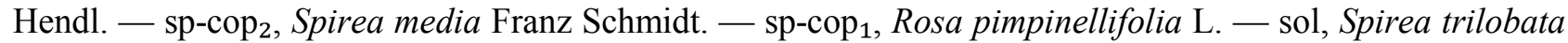
L. - sol, Cotoneaster melanocarpus Fisch. ex Blytt — sol, Ribes rubrum L. - sol, Caragana arborescens Lam. - sp.

The herbaceous layer is well developed and rich in species. Layering in the herbage is not expressed. Typical species are Bistorta major S.F. Gray - sol, Bupleurum longifolium L. subsp. aureum (Fisch. ex Hoffm.) - sol, Sedum hybridum L. - sol, Dactylis glomerata L. - sol, Thalictrum flavum L. - sp, Lamium album L. - sol, Hierocloeodorata (L.) Beauv. - sol, Veratrum nigrum 1. — sol, GaliumverumL. — sol-sp, Atragene sibirica L. — sol, Urticadioica L. — sol-cop ${ }_{2}$, Phleum phleoides (L.) Karst. — sol, Artemisia sieversiana Willd. — sp — $\mathrm{cop}_{1}$, Ferula songarica Pall. ex Spreng. — sol, Artemisia vulgaris L. sol, Saussurea latifolia Ledeb. - sol, Elytrigia repens (L.) Nevski — sol, Dactylis glomerata L. — sol.

The fir population is represented by all age groups. The plants are well developed. Undergrowth is abundant: young individuals up to $50 \mathrm{~cm}$ high - up to $15-20$ pieces per $100 \mathrm{~m}^{2}$, up to $1 \mathrm{~m}$ high $-7-10$ pieces per $100 \mathrm{~m}^{2}$. Annual growth varies from 2.5 to $3.8(3.1 \pm 0.4 ; \mathrm{Cv}=24 \%) \mathrm{cm}$. The length of young needles is $1.3-2.2(1.8 \pm 0.2 ; \mathrm{Cv}=22 \%) \mathrm{cm}$.

Young aspen ispredominate along the north-western periphery.

The intermontane slope valley consists of $P$. tremula L. и $A$. sibirica Ledeb. Individuals of $A$. sibirica are tall, up to $17-18 \mathrm{~m}$ height. Aspen is the predominant species. A. sibirica Ledeb. located in small groups of 2-3 mature forms, less often in longitudinal stripes. The eastern spurs are characterized by small islets of $P$. tremula, about $100 \mathrm{~m}^{2}$ each, arranged in longitudinal stripes. The undergrowth is dominated by: Sorbus sibirica Hedl., Spirea media Franz Scmidt, Rosa pimpinellifolia L.

The northern slopes are located in the foothill part of Mountain Medvedka. Location coordinates: $49^{\circ}$ $34^{\prime} 44^{\prime \prime} \mathrm{N}, 82^{\circ} 36^{\prime} 20^{\prime \prime} \mathrm{E}, 1289 \mathrm{~m}$ above sea level. Three types of communities represent the slope.

Cenopopulation of birch-fir (B. pendula Roth, A. sibirica Ledeb.) phytocenosis. The relief of the slope is leveled, with a steepness of $10-15^{\circ}$, in some places up to $25^{\circ}$. Most of the granitoid slabs are completely enclosed; it is very rare to find rock outcrops. The soils are well formed and very dense. Soil horizon is 40 $45 \mathrm{~cm}$ deep, in depressions up to $50 \mathrm{~cm}$. Vegetable litter is significant, well overheated, $100-120 \mathrm{~g} / \mathrm{m}^{2}$, consists of needles and dry foliage of cereals. The investigated area is heavily littered with felled and windblown trees, which in the future can be a source of wood pests. Shrub layer up to $150 \mathrm{~cm}$ tall, well-formed, has a density up to 05-06. Commonly seen species are: Caragana arborescens Lam. - sol-sp, Spirea media Franz Scmidt - sol, Ribes rubrum L., Cotoneaster multiflorus Bunge. In the herbage typical species are: 
Caragana arborescens Lam. - sol-sp, Spirea media Franz Scmidt - sol, Ribes rubrum L., Cotoneaster multiflorus Bunge. In herbage, common species are: Agrostis gigantea Roth, Polemonium caeruleum L., Carex humilis Leyss, Bupleurum longifolium L. subsp. aureum (Fisch. ex Hoffm.) Soo, Viola hirta L., Saussurea latifolia Ledeb., Serratula coronate L., Cuscuta europaea L., Lathyrus gmelinii Fritsch., Silene graminifolia Otth, Galatella hauptii (Ledeb.) Lindl., Aconitum septentrionale Koelle, Dryopteris filix-mas (L.) Schott, Asplenium septentrionale (L.) Hoffm.

The age composition of the studied species is represented by all age groups. Fir undergrowth is abundant in small illuminated glades under the canopy of herbage, in small dense groups of 10-20 plants in the stage of seedlings and juvenile phase. The annual growth is from 3.3 to $4.2(3.8 \pm 0.2 ; \mathrm{Cv}=22 \%) \mathrm{cm}$. The length of young needles is $1.8-2.3(2.1 \pm 0.1 ; \mathrm{Cv}=15 \%) \mathrm{cm}$.

Mature forms of A. sibirica Ledeb. are tall, up to 15-18 $\mathrm{m}$ height. The crowns of the trees are symmetrical, oblong-conical. Frost cracks on fir trunks are quite common.

Cenopopulation of fir (A. sibirica Ledeb.) phytocenosis is rare. It occupies gentle plains. The soils are well formed. The herbaceous layer is almost not pronounced and presented by: Lythurus gmelinii Fritsch sol, Veratrum nigrum L. - sol-sp, Thalictrum simplex L. — sp, Rubus idaes L. — sol, Crepis sibirica L. sol, Viola hirta L. - sol, Cirsium helenioides (L.) Hill — sol, Ribes rubrum L. — sol, Sorbus sibirica Hedl. - sol. Other related species which should be distinguished: Aconitum anthoroideum DC., Juniperus sabina L., Cotoneaster melanocarpus Fisch. ex Blytt, Ribes nigrum L., Lonicera tatarica L., Chelidonium majus L., Bromopsis inermis (Leyss.) Holub, Agropyron desertorum (Fisch. ex Link) Schult., Stipa pennata L., Achillea millefolium L., Pinus sylvestris L., Erysium flavum (Georgi) Bobr., Antennaria dioica (L.) Gaertn., Poa angustifolia L., Festuca valesiaca Gaudin, Allium nutans L., Rheum compactum L.

Individuals of A. sibirica are well formed and tall, up to 17-19 m height. Frost cracks are quite common; there are no diseases and pests. The lower branches are mostly bare. The annual growth is from 2.1 to $3.2(2.7 \pm 0.3 ; \mathrm{Cv}=25 \%) \mathrm{cm}$. The length of young needles is $1.6-2.1 \mathrm{~cm}(1.8 \pm 0.1 ; \mathrm{Cv}=19 \%)$. Undergrowth is unsatisfactory, in the amount of $2-4$ plants. Senile individuals prevail.

Cenopopulation of fir-aspen phytocenosis (P. tremula L., A. sibirica Ledeb.) usually occupies slopes with a high steepness of $25-35^{\circ}$. The soils are well formed. The soil horizon is $40-50 \mathrm{~cm}$. The water balance is compiled by precipitation. There is no groundwater supply.

Tree layer is presented by P. tremula L. - sp-cop 1 , A. sibirica Ledeb. - $\operatorname{cop}_{1}-\mathrm{cop}_{2}$, B. pendula Roth - sol. There are commonly located shrubs: Spiraea media Franz Schmidt - sol, Caragana arborescens Lam. - sol. The herbaceous layer is well formed, up to $100-120 \mathrm{~cm}$ in height. It is presented by: Lathyrus gmelinii Fritsch - $\mathrm{cop}_{2}$, Cirsium helenioides (L.) Hill. — sol-cop $_{2}$, Bupleurum longifolium L. subsp. aureum (Fisch. ex Hoffm.) Soo — sol, Paeonia anomala L. — sol, Thalictrum simplex L. — sol, Veratrum lobelianum Bernh. - sol, Hierocloë odorata (L.) Beauv. — sol, Urtica dioica L. — sol, Dactylis glomerata L. - sol, Delphinium elatum L. — sol, Artemisia dracunculus L. — sol, Poa nemoralis L. — sol, Viola hirta L. - sol, Saussurea latifolia Ledeb. - $\operatorname{cop}_{2}$, Festuca altissima All. - cop ${ }_{1}$, Crepis sibirica L. - sol, Bistorta mayor S.F. Gray — sol, Rubus saxatilis L. — sol, Filipendula ulmaria (L.) Maxim. — sol, Artemisia sieversiana Willd. - sol, Serratula coronata L. - sol, Filipendula vulgaris Moench — sol, Trollius altaicus C.A. Mey. — sol, Geum aleppicum Jacq. — sol, Carex macroura Meinsh. — sol, Dryopteris filix-mas (L.) Schott - sol, Gymnocarpium dryopteris (L.) Newm. - sol.

A. sibirica Ledeb. is tall, 14-17 $\mathrm{m}$ in height. Cenopopulation with a left-sided spectrum is represented by all growth phases. The undergrowth is abundant, but sparse in this phase, $2-5$ juveniles per $100 \mathrm{~m}^{2}$. The annual growth is from 2 to $2.8(2.3 \pm 0.2 ; \mathrm{Cv}=28 \%) \mathrm{cm}$. The length of young needles is $1.5-2(1.7 \pm 0.2$; $\mathrm{Cv}=23 \%) \mathrm{cm}$. There are crowns of the correct form with a skirted base. It is rare to find trees with curved crowns. No diseases or pests were found. Frost cracks is commonly appearing.

Analysis of the data (Tab. 1) showed that the state of the species, the degree of regeneration and the amount of young fir undergrowth directly depends on the community and other species dominating in the tree layer. It was found that fir-birch phytocenoses are the most stable and productive. The species in such communities is characterized by high vitality and resistance to pests and diseases. As a rule, such communities are occupied by overgrown granitoid massifs. In aspen-fir phytocenoses a gradual suppression of A. sibirica Ledeb is observed. The P. tremula usually forms dense clonal groups and significantly limits the distribution of fir. In addition, the root-sprouting undergrowth of aspen displaces the fir undergrowth, and does not allow full development. Usually, this type of community is confined to flat areas.

Pure fir communities are quite rare. They occupy steep, flat slopes are vulnerable to diseases and pests. 
Table 1

Comparison of metric features of the studied cenopopulations

\begin{tabular}{|c|c|c|c|c|}
\hline Community name & $\begin{array}{l}\text { Annual growth rate, } \\
\qquad \mathrm{cm}\end{array}$ & $\begin{array}{c}\text { The length of the } \\
\text { annual growth of } \\
\text { needles, cm }\end{array}$ & $\begin{array}{l}\text { Height of } \\
\text { mature } \\
\text { trees, } \mathrm{m}\end{array}$ & $\begin{array}{l}\text { The number of } \\
\text { young under- } \\
\text { growth per } 100 \mathrm{~m}^{2}\end{array}$ \\
\hline \multicolumn{5}{|c|}{ East slope } \\
\hline $\begin{array}{l}\text { Fir phytocenosis (A. sibirica } \\
\text { Ledeb.) }\end{array}$ & $\begin{array}{c}2-6 \\
3,55 \pm 1 ; 37 \%\end{array}$ & $\begin{array}{c}1,2-1,5 \\
1,4 \pm 0,27 ; 22 \%\end{array}$ & $7-18$ & $2-4$ \\
\hline \multicolumn{5}{|c|}{ Southeastern peak } \\
\hline $\begin{array}{l}\text { Fir-birch phytocenosis (B. pendula } \\
\text { Roth, A. sibiricaL.) }\end{array}$ & $\begin{array}{c}2-3 \\
2,35 \pm 0,28 ; 17 \%\end{array}$ & $\begin{array}{c}1,5-2 \\
1,88 \pm 0,14 ; 11 \%\end{array}$ & $15-20$ & $2-6$ \\
\hline \multicolumn{5}{|c|}{ Northwest peak } \\
\hline $\begin{array}{l}\text { Fir-aspen phytocenosis } \\
\text { (A. sibirica Ledeb., P. tremula L., } \\
\text { B. pendula } \text { Roth.) }\end{array}$ & $\begin{array}{c}2,2-3 \\
2,67 \pm 0,5 ; 5 \%\end{array}$ & $\begin{array}{c}1-2,5 \\
1,85 \pm 0,39 ; 28 \%\end{array}$ & $15-22$ & $2-7$ \\
\hline \multicolumn{5}{|c|}{ Western slope of the mountain } \\
\hline $\begin{array}{l}\text { Aspen-fir phytocenosis } \\
\text { (P. tremula L., A. sibirica Ledeb.) }\end{array}$ & $\begin{array}{c}2-2,8 \\
2,4 \pm 0,3 ; 17 \% \\
\end{array}$ & $\begin{array}{c}1-1,8 \\
1,3 \pm 0,2 ; 21 \% \\
\end{array}$ & $15-17$ & $2-3$ \\
\hline $\begin{array}{l}\text { Birch-fir communities (B. pendula } \\
\text { Roth, } A \text {. sibirica Ledeb.). }\end{array}$ & $2,5-3,83,1 \pm 0,4 ; 24 \%$ & $\begin{array}{c}1,3-2,2 \\
1,8 \pm 0,2 ; 22 \%\end{array}$ & $17-18$ & $7-10$ \\
\hline \multicolumn{5}{|c|}{ Northern slopes of the foothill part } \\
\hline $\begin{array}{l}\text { Cenopopulation of birch-fir } \\
\text { phytocenosis ( } B \text {. pendula Roth, } A \text {. } \\
\text { sibirica Ledeb) }\end{array}$ & $\begin{array}{c}3,3-4,2 \\
3,8 \pm 0,2 ; 22 \%\end{array}$ & $\begin{array}{c}1,8-2,3 \\
2,1 \pm 0,1 ; 15 \%\end{array}$ & $15-18$ & $10-20$ \\
\hline $\begin{array}{l}\text { Cenopopulation of fir } \\
\text { phytocenosis ( } \text {. } \text {. sibirica Ledeb.) }\end{array}$ & $\begin{array}{c}2,1-3,2 \\
2,7 \pm 0,3 ; 25 \%\end{array}$ & $\begin{array}{c}1,6-2,1 \\
1,8 \pm 0,1 ; 19 \%\end{array}$ & $17-19$ & $2-4$ \\
\hline $\begin{array}{l}\text { Cenopopulation of fir-aspen } \\
\text { phytocenosis ( } P \text {. tremula L., } A \text {. } \\
\text { sibirica Ledeb.) }\end{array}$ & $\begin{array}{c}2-2,8 \\
2,3 \pm 0,2 ; 28 \%\end{array}$ & $\begin{array}{c}1,5-2 \\
1,7 \pm 0,2 ; 23 \%\end{array}$ & $14-17$ & $2-5$ \\
\hline
\end{tabular}

Conclusion

Siberian fir occupies most on the the eastern, northern and western slopes of the Mountain Medvedka, as well as two peaks. The plants are well developed. The population is represented by all age groups. The species form 3 types of phytocenoses: birch-fir (B. pendula Roth, A. sibirica Ledeb), fir (A. sibirica Ledeb.) and fir-aspen ( $P$. tremula L., A. sibirica Ledeb.).

The main task was to establish the state and degree of renewal of the endangered species. In this regard, such parameters as the height of mature trees, annual growth, length of young needles and the amount of young undergrowth were determined. It was found that the type of phytocenosis and the role it plays in the community, and other dominant species in the tree layer directly affect the regeneration, the state of the species and the amount of young fir undergrowth.

It was established that only birch-fir communities are characterized by optimal conditions. In communities with aspen the species is severely oppressed. Diseases and pests were found in clean plantations.

The main limiting factors for the species are an extreme ecological habitat conditions and the lack of an adequate soil layer.

Protection measures such as constant monitoring of the state of the population, artificial resewing of fir seeds and planting seedlings to increase regeneration were recommended.

\section{Acknowledgements}

The article was prepared with the financial support of Science Technical Program «Development of scientific-practical foundations and innovative approaches in plant introduction in natural zones of Western and Eastern-Kazakhstan for rational-effective use» of the Ministry of Education and Science of the Republic of Kazakhstan for 2021-2022. 


\title{
References
}

1 Voronchev V.T. Analysis of the structure and properties of nuclei with A $=9$ (9Be-9B) in the dynamic multicluster $2 \alpha+\mathrm{N}$ model / V.T. Voronchev, V.I. Kukulin, V.N. Pomerantsev, Kh. D. Razikov, G.G. Ryzhikh // Yad. Fiz. — 1994. — Vol. 57. — P. 1964.

2 Буркова Н.А. Потенциальная теория кластерного фоторасщепления легких ядер / Н.А. Буркова, К.А. Жаксыбекова, М.А. Жусупов // Физика элементарных частиц и атомного ядра. - 2005. — Т. 36. Вып. 4. — С. 801-868.

3 Larionova A.Y. Genetic Diversity and Population Structure of Siberian fir (Abies sibirica Ledeb.) in Middle Siberia, Russia / A.Y. Larionova, A.K. Ekart, A.N. Kravchenko // Eurasian Journal of Forest Researc. — 2007. — Vol. 10, Issue 2. — P. $185-192$.

4 Нухимовская Ю.Д. Онтогенез пихты сибирской (Abies sibirica Ledeb.) в условиях Подмосковья / Ю.Д. Нухимовская // Бюлл. Моск. общ. испыт. природы. Отд. биол. - 1971. — T. LXXVI (2). — C. 105-112.

5 Егорина А.В. Барьерные ландшафты Калбинского нагорья / А.В. Егорина, А.Н. Логиновская // ИнтерЭкспоГеоСибирь. - 2012. - Т. 2, № 3. - С. 153-156.

6 Егорина А. В. О формировании туристского кластера в Восточном Казахстане / А.В. Егорина // Сервис и туризм: инновации, теория и практика: материалы ХІ Междунар. науч. -практ. конф. - Абакан: ХГУ, 2011. — С. 32-41.

7 Егорина А.В. Туристские объекты Калбинского Алтая и возможности их использования в рекреационных целях / А.В. Егорина, Ю.А. Теплова. — Барнаул: АлтТГУ им. И. Ползунова, 2013. — С. 47-50.

8 Егорина А.В. Ландшафты Южного Алтая как объекты туризма / А.В. Егорина, Н.Ж. Женсикбаева // Вестн. ВКГТУ им. Д. Серикбаева. - 2011. - № 4. - С. 104-107.

9 Некрасова Т.П. Плодоношение пихты сибирской / Т.П. Некрасова, А.П. Рябинков. - Новосибирск: Наука, 1978. $151 \mathrm{c}$.

10 Третьякова И.Н. Эмбриология хвойных: физиологические аспекты / И.Н. Третьякова. - Новосибирск: Наука, 1990. $-182 \mathrm{c}$.

11 Bazhina E.V. Seed Production and Quality of Siberian Fir in the Region affected by the Baikal Pulp-and-Paper Mill / E.V. Bazhina // Лесоведение. — 1998. — № 2. - C. 10-15.

12 Кокорин Д.В. Формовое разнообразие пихты сибирской в южных районах Средней Сибири / Д.В. Кокорин, Л.И. Милютин // Лесоведение. - 2003. — № 4. - С. 32-35.

13 Быков Б.А. Геоботаника / Б.А. Быков. - Алма-Ата: Изд-во АН КазССР, 1957. — 381 с.

14 Голубев В.Н. Методические указания к популяционно-количественному и эколого-биологическому изучению редких, исчезающих и эндемичных растений Крыма / В.Н. Голубев, Е.Ф. Молчанов. — Ялта: Никитский ботанический сад, 1978. - $41 \mathrm{c}$.

15 Денисова Л.В. Программа и методика наблюдений за ценопопуляциями видов Красной книги СССР / Л.В. Денисова, С.В. Никитина, Л.Б. Заугольникова. - М.: Госагропром СССР; ВНИИ охраны природы и заповедного дела, $1986 .-125$ с.

16 Серебряков И.Г. Экологическая морфология растений / И.Г. Серебряков. - М.: Высш. шк., 1962. - 378 с.

17 Быков Б.А. Введение в фитоценологию. — Алма-Ата: Изд-во АН КазССР, 1970. — 226 с.

18 The Plant List. Version 1.1. Electronic resource: http://www.theplantlist.org

\section{А.А. Сумбембаев, А.Н. Данилова}

\section{«Синегорск шыршалы тоғай» табиғи ескерткішіндегі (Көк таулары) Abies sibirica Ledeb.реликті түрінің жағдайы}

\begin{abstract}
Мақалада «Синегорск шыршалы тоғай» табиғи ескерткішіндегі Ciбip шыршасын (Abies sibirica Ledeb.) зерттеудің нәтижелері келтірілген. Реликт популяциясының қазіргі жағдайымен дамуын зерттеу мақсатында далалық экспедициялар өткізілді. Маршруттық-барлау әдісі негізінде Медведка тауындағы популяцияның негізгі өсетін аймақтары: шығыс, солтүстік және батыс беткейлері, сондайақ екі шыңы зерттелді. Зерттелген популяция әрбір жас топтарымен ұсынылған. A. sibirica Ledeb. 3 негізгі фитоценоздардың түрін құрайды: қайың-шырша (Betula pendula Roth, A. sibirica Ledeb.), шырша (A. sibirica Ledeb.) және шырша-көктерек (Рориlus tremula L., A. sibirica Ledeb.). Жетілген ағаштардың биіктігі, жылдық өсуі, жас инелердің ұзындығы және жас өсінділердің мөлшері сияқты параметрлер анықталды. Түрдің регенерациясы фитоценоздың түріне тікелей байланысты екендігі айқындалды. Сібір шыршасының күйін, жаңаруын және таралуын бақылау нәтижелері бойынша тек қайың-шыршалар қауымдастығы оңтайлы жағдайлармен сипатталатындығы анықталды. Көктерек түрі қауымдастықтарда бұл қатты қысымға түседі. Таза отырғызылғандардан аурулармен зиянкестер табылды. Түрлер үшін шектеуші факторлар — тіршілік ету ортасының ксерофиттелуі және жеткілікті топырақ қабатының болмауы. Қосымша қорғаныс шаралары ретінде популяцияның жағдайын үнемі бақылау, регенерацияны арттыру үшін тұқымдарды жасанды қайта себу және шырша көшеттерін отырғызу ұсынылған.
\end{abstract}

Kiлm сөздер: Abies sibirica Ledeb., Қалба жотасы, Синегорск шыршалы тоғайы, реликт түрлері, ценопопуляция. 
А.А. Сумбембаев, А.Н. Данилова

\title{
Состояние реликтового вида Abiessibirica Ledeb. в памятнике природы «Синегорская пихтовая роща» (горы Коктау)
}

\begin{abstract}
В статье изложены результаты исследований пихты сибирской (Abies sibirica Ledeb.) в памятнике природы «Синегорская пихтовая роща». С целью изучения текущего состояния и развития реликтовой популяции проведены полевые экспедиционные выезды. На основе маршрутно-рекогносцировочного метода изучены основные занимаемые площади популяции на горе Медведка: восточный, северный и западный склоны, а также две вершины. Изучаемая популяция представлена всеми возрастными группами. A. sibirica Ledeb. образует 3 основных типа фитоценозов: березово-пихтовый (Betula pendula Roth, A. sibirica Ledeb.), пихтовый (A. sibirica Ledeb.) и пихтово-осиновый (Populus tremula L., A. sibirica Ledeb.). Определены такие параметры, как высота взрослых деревьев, годовой прирост, длина молодой хвои и количество молодого подроста. Установлено, что возобновление вида напрямую зависит от типа фитоценоза. По результатам наблюдений за состоянием, возобновлением и расселением пихты сибирской установлено, что оптимальными условиями характеризуются только березово-пихтовые сообщества. В сообществах с осиной вид испытывает сильное угнетение. В чистых насаждениях обнаружены болезни и вредители. Лимитирующими факторами для вида являются ксерофитизация условий обитания и отсутствие достаточного почвенного слоя. В качестве дополнительных мер охраны предложены постоянный контроль за состоянием популяции, искусственный подсев семян и посадка саженцев пихты для увеличения возобновления.
\end{abstract}

Ключевые слова: Abies sibirica Ledeb., Калбинский хребет, Синегорская пихтовая роща, реликтовый вид, ценопопуляция.

\section{References}

1 Voronchev, V.T., Kukulin, V. I., Pomerantsev, V. N., Razikov, Kh. D. \& Ryzhikh, G.G. (1994). Analysis of the structure and properties of nuclei with $\mathrm{A}=9$ (9Be-9B) in the dynamic multicluster $2 \alpha+\mathrm{N}$ model. Yad. Fiz., 57; 1964.

2 Burkova, N.A., Zhaksybekova, K.A. \& Zhusupov, N.A. (2005). Potentsialnaia teoriia klasternogo fotorasshchepleniia legkikh yader [Potential theory of cluster photodisplay of light nuclei]. Phys. Part. Nucl., 36, 4; 801-868 [in Russian].

3 Larionova, A.Y., Ekart, A.K. \& Kravchenko, A.N. (2007). Genetic Diversity and Population Structure of Siberian fir (Abies sibirica Ledeb.) in Middle Siberia, Russia. Eurasian Journal of Forest Research, 10 (2); 185-192.

4 Nukhimovskaya, Yu. D. (1971). Ontogenez pikhty sibirskoi (Abies sibirica Ledeb.) v usloviiakh Podmoskovia [Ontogenesis of spur sibirskiya (Abies sibirica Ledeb.) in the conditions of Moscow region]. Bulleten Moskovskogo obshchestva ispytatelli prirody. Otdelenie Biologiia - Bulletin of the M. island nature, Dept. Biology, LXXVI (2); 105-112 [in Russian].

5 Egorina, A.V. \& Loginovskaya, A. N. (2012). Barernye landshafty Kalbinskogo nagoria [Barrier landscapes of the Kalba Upland]. InterEkspoGeo-Sibir - Interexpo Geo-Siberia, 2 (3); 153-156 [in Russian].

6 Egorina, A.V. (2011). O formirovanii turistskogo klastera v Vostochnom Kazakhstane [On the formation of a tourist cluster in East Kazakhstan]. Service and tourism: innovations, theory and practice: materialy XI Mezhdunarodnoi naucho-prakticheskoi konferentsii - materials of the XI Intern. scientific-practical conf. Abakan: KSU [in Russian].

7 Egorina, A.V. \& Teplova, Yu.A. (2013). Turistskie obekty Kalbinskogo Altaia i vozmozhnosti ikh ispolzovaniia $v$ rekreatsionnykh tseliakh [Tourist objects of Kalba Altai and the possibility of their use for recreational purposes]. Barnaul: AltTGU imeni I. Polzunova [in Russian].

8 Egorina, A.V. \& Zhensikbaeva, N.Zh. (2011). Landshafty Yuzhnogo Altaia kak obekty turizma [Landscapes of the Southern Altai as objects of tourism]. Vestnik VKGTU imeni D. Serikbaeva - Bulletin of Eastern-Kazakhstan State Tewchnical University named D. Serikbaeva, 4; 104-107 [in Russian].

9 Nekrasova, T. P. \& Ryabinkov, A. P. (1978). Plodonoshenie pikhty sibirskoi [Fruiting of Siberian Fir]. Novosibirsk: Nauka [in Russian].

10 Tretyakova, I.N. (1990). Embriologiia khvoinykh: fiziologicheskie aspekty [Coniferous Embryology: Physiological Aspects]. Novosibirsk: Nauka [in Russian].

11 Bazhina, E.V. (1998). Seed Production and Quality of Siberian Fir in the Region Affected by the Baikal Pulp-and-Paper Mill. Lesovedenie - Forest Study, 2; 10-15.

12 Kokorin, D.V. \& Milyutin, L.I. (2003). Formovoe raznoobrazie pikhty sibirskoi v yuzhnykh raionakh Srednei Sibiri [Form Variability of the Siberian Fir in Southern Taiga Regions of the Middle Siberia]. Lesovedenie — Forest Study, 3; 76 -79 [in Russian].

13 Bykov, B.A. (1957). Geobotanika [Geobotany]. Alma-Ata: Izdatelstvo AN KazSSR [in Russian].

14 Golubyev, V. N. \& Molchanov, E. F. (1978). Metodicheskie ukazaniia k populiatsionno-kolichestvennomu $i$ ekologobiologicheskomu izucheniiu redkikh, ischezaiushchikh $i$ endemichnykh rastenii Kryma [Guidelines for population-quantitative and ecological-biological study of rare, endangered and endemic plants of the Crimea]. Yalta: Nikitskii botanicheskii sad [in Russian].

15 Denisova, L.V., Nikitina, S.V. \& Zaugolnova, L.B. (1986). Programma i metodika nabliudenii za tsenopopuliatsiiami vidov Krasnoi knigi SSSR [Program and methodology for observing cenopopulations of species in the Red Data Book of the USSR]. Moscow: Gosagroprom of the USSR; All-Russian Research Institute of Nature Conservation and Reserve Management [in Russian]. 
16 Serebryakov, I.G. (1962). Ekologicheskaia morfologiia rastenii [Ecological morphology of plants]. Moscow: Vysshaia shkola [in Russian].

17 Bykov, B.A. (1970). Vvedenie v fitotsenologiiu [Introduction to phytocenology]. Alma-Ata: Izdatelstvo AN KazSSR [in Russian].

18 The Plant List. Version 1.1. Retrived from http://www.theplantlist.org 